\title{
Differences in the spatial patterns of urban tourism in Vienna and Prague
}

In Central Europe the two major urban tourism destinations are Vienna and Prague - with both registering the same number of foreign arrivals in 2011. Despite the two cities being similar in their size and range of cultural tourism, they differ significantly in tourists' spatial distribution and space usage. In Prague, congestion, overcrowding and the mono-functional use of the city centre is well known and documented, whereas in Vienna the city centre hosts a similar number of visitors without conflicts between local functions and tourism. Data obtained from geographically-referenced photography of the two cities uploaded to image-sharing web sites were used to build graphs of the spatial distribution of tourist attractions and routes. Analysing these comparable graphs resulted in some possible explanations regarding the differences in the two cities' tourist systems. These are mainly related to the morphological layout of the two cities and their divergent approaches to developing urban tourism infrastructures over the past decade.

Key words: urban tourism, urban morphology, impact of tourism, urban space usage, geotagging, Vienna, Prague 


\section{Introduction}

Vienna and Prague are both cities known throughout the world for their historical urban scenes, architectural monuments and cultural points of interest. In 2011 Prague and Vienna ranked sixth and seventh among cities of the European Union according to TourMIS annual data (2012), with Prague having more tourist bed nights and Vienna more tourist arrivals. As preferred standalone weekend destinations, a large number of tourists visit Vienna, Prague and Budapest together in a Central-Eastern European round-trip (Puczkó \& Rátz, 2000). These three important cities of the former Habsburg Empire have similar tourist attractions; however, over the past twenty years Budapest has been attracting only half the number of visitors as its rivals. Vienna and Prague have similar tourism industries at first sight, but there are important differences in history, urban planning practices and tourism destination management. The same numbers of visitors use two urban structures with different morphologies, resulting in very contrasting tourism impacts on the local systems of these cities.

Tourists in cities consume a series of experiences ranging from sights, monuments, museums or cultural events to shopping, dining and interaction with other people. Cities compete on the global market for tourists by developing their attractions and their urban surroundings. However, in tourist-historic cities (Ashworth \& Turnbridge, 1990) like Vienna and Prague, the majority of attractions and their urban settings are monuments in historical urban layouts with an evolved and protected morphology, also used by the local community with their own infrastructures, businesses and cultural uses. These cities have improved their tourism attractiveness in the past decade by improving the pedestrian access in their city centres and by developing their cultural tourism services and their commercial and retail services, along with the necessary refurbishment of streets and historical buildings. However, as increasingly more visitors now gather in the pedestrian-friendly public spaces around the main monuments, the space for local uses diminishes. Grocery stores and workshops turn into souvenir shops and local pubs into fancy restaurants, and entire apartment buildings are converted into hotels because these are now more profitable services and businesses. Locals are generally disturbed by the overcrowded neighbourhoods and move out into suburbs or other parts of the city where parking, local services and tranquillity are more accessible. This resulting exodus produces a mono-functional city centre that loses its urban character by processes of "museumification" or "Disneyfication" (McNeil, 1999). Boštjan Bugarič (2006) notes that the "touristification" of cities diminishes the quality of life and public presence of its locals. These processes and the negative effects of tourist congestion have been described by scholars analysing these effects on locals' attitudes (see
Gilbert \& Clark, 1997; Deichmann, 2002) and visitors (see Simpson, 1999; Riganti \& Nijkamp, 2008).

Published studies (see Johnson, 1995; Cooper \& Morpeth, 1998; Hoffman \& Musil, 1999; Simpson, 1999; Deichmann, 2002; Hoffman \& Musil, 2009) support the assumption resulting from this location analysis of tourist and local infrastructures and the author's experiences on location: Prague suffers from many more of these symptoms. In Prague the presence of tourists is stronger in the central areas, causing reported situations of tourist congestion and the almost complete withdrawal of local users and infrastructures. In Vienna only restricted parts of the centre are completely appropriated by tourists. This raises the question of why one city can resist the pressure of a similar number of tourists but another cannot.

This paper focuses on the major differences in tourist space usage between the two cities and reviews the published cases of social and spatial tensions caused by urban tourism. Using a comparable model of urban tourist space usage, it offers an explanation for why the same number of visitors is causing more problems in Prague than in Vienna.

\section{Tourists in Vienna and Prague}

Both cities attract the same type of tourists from the same countries, with more domestic tourists visiting the Austrian capital, compensated by more Russian, Polish and American tourists in Prague (Table 1). Both are equally popular destinations for cultural tourism as "weekend city visits" - with many cheap flights now connecting to their airports in the past decade. And with both being former capitals of empires they share a strong historical atmosphere and the typical urbanity of Mitteleuropa on which they both promote most of their tourism. Prague flourished in the era of the Holy Roman Empire, especially under Charles IV in the fourteenth century and later under Rudolf II in the sixteenth century. Vienna, on the other hand, became the capital of the Holy Roman Empire after Prague, in the fifteenth century; but lost its cultural importance during the Turkish wars of the sixteenth and seventeenth centuries. As the capital of the Habsburg Empire, and later of the Austro-Hungarian Empire, Vienna again flourished in the eighteenth and nineteenth centuries, right up until the First World War. The two cities survived the two world wars relatively untouched, thus preserving a heritage that is very well marketable today. Vienna was able develop in a steady political and economic environment following the Second World War, whereas Prague's course was more difficult. Fortunately for today's tourists, the integrity and preservation of Prague's historical urban landscape and monuments was an important issue for Czech intellectuals from the early nineteenth century onwards and also during 
Table 1: Tourist arrivals in Vienna and Prague in 2012.

\begin{tabular}{|c|c|c|c|c|}
\hline City & Prague & & Vienna & \\
\hline Market & Absolute & Total (\%) & Absolute & Total (\%) \\
\hline Domestic & 713,537 & 13.2 & $1,438,736$ & 23.7 \\
\hline Austria & 103,725 & 1.9 & & \\
\hline France & 226,883 & 4.2 & 154,309 & 2.5 \\
\hline Germany & 659,504 & 12.2 & $1,067,567$ & 17.6 \\
\hline Italy & 293,526 & 5.4 & 268,652 & 4.4 \\
\hline Spain & 181,841 & 3.4 & 192,173 & 3.2 \\
\hline Switzerland & 59,248 & 1.1 & 174,235 & 2.9 \\
\hline United Kingdom & 295,637 & 5.5 & 207,272 & 3.4 \\
\hline Other former Western Europe & 533,144 & 9,9 & 474,803 & 7.8 \\
\hline Former Western Europe (totals) & $2,353,508$ & 43.6 & $2,539,011$ & 41.8 \\
\hline Czech Republic & & & 86,152 & 1.4 \\
\hline Hungary & 74,992 & 1.4 & 86,558 & 1.4 \\
\hline Poland & 155,154 & 2.9 & 76,181 & 1.3 \\
\hline Russia & 470,039 & 8.7 & 279,641 & 4.6 \\
\hline Other former Eastern Bloc & 418,847 & 7.6 & 286,565 & 4,7 \\
\hline Former Eastern Bloc (totals) & $1,119,032$ & 20.6 & 815,097 & 13.4 \\
\hline Europe (total foreign) & $3,472,540$ & 64.0 & $3,354,108$ & 55.0 \\
\hline United States and Canada & 372,145 & 6.9 & 328,646 & 5.0 \\
\hline Other American markets & 135,100 & 3 & 112,461 & 2 \\
\hline The Americas (totals) & 507,245 & 9.4 & 441,107 & 7.3 \\
\hline China & 98,192 & 1.8 & 126,959 & 2.1 \\
\hline India & 20,521 & 0.4 & 26,181 & 0.4 \\
\hline Israel & 74,096 & 1.4 & 40,286 & 0.7 \\
\hline Japan & 104,909 & 1.9 & 161,024 & 2.6 \\
\hline South Korea & 78,782 & 1.5 & 60,078 & 1.0 \\
\hline Other Asian markets & 134,170 & 2.5 & 203,637 & 3.4 \\
\hline Asia & 510,670 & 9.5 & 618,165 & 10.2 \\
\hline Africa & 28,117 & 0.5 & 30,783 & 0.5 \\
\hline Oceania & 68,473 & 1.2 & 69,999 & 1.1 \\
\hline Unspecified markets & 93,701 & 2.0 & 124,387 & 2.0 \\
\hline Total foreign & $4,680,746$ & 86.8 & $4,638,549$ & 76.3 \\
\hline Total foreign and domestic & $5,394,283$ & 100.0 & $6,077,285$ & 100.0 \\
\hline
\end{tabular}

Source: TourMIS (2012)

communism because they were considered representational proof of Czech national identity (Hoffman \& Musil, 1999; Simpson, 1999). Surprisingly, these conservationist ideas were helped by the communist economic structure itself because the centralised price and rent controls prevented central locations from becoming targets for property development (Cooper \& Morpeth, 1998). As a result, the original Medieval-Baroque urban morphology was completely preserved, leading to the Old Town (Cz. Staré Mèsto), Little Quarter (Cz. Malá Strana) and New Town (Cz. Nové Mèsto) being listed together as a UNESCO World Heritage site in 1992, much earlier than in the centre of Vienna, listed only in 2003.

The major difference in the tourist usages of these historical centres comes from their diverse urban morphologies and the differing development of their tourism industries in the second half of the twentieth century. 


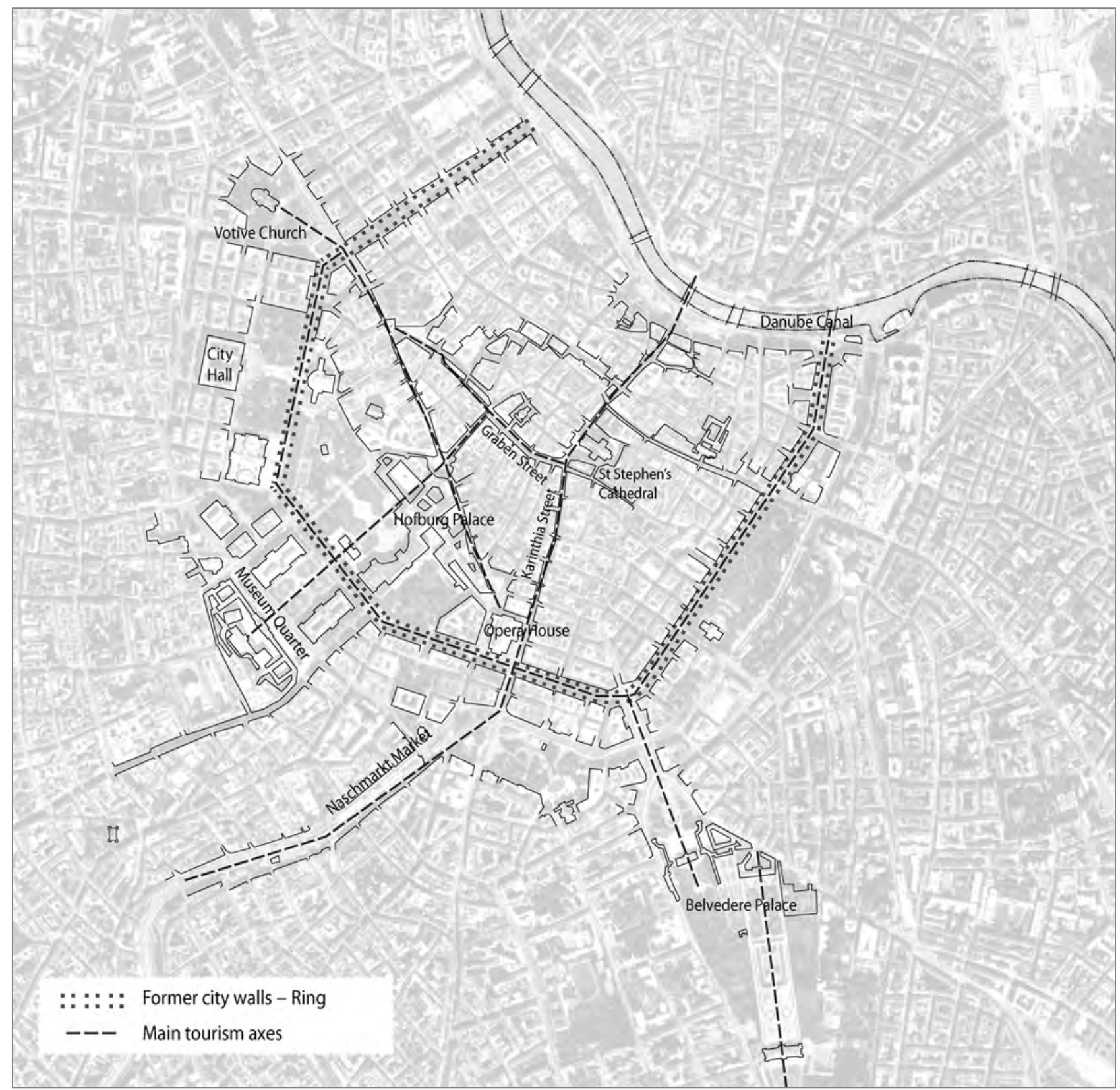

Figure 1: Main morphological and tourist elements in Vienna.

\subsection{Morphology of two historical cities}

The two cities have quite different morphological layouts as defined by their topography and historical development in urban design.

The historical centre of Vienna is situated on the right bank of the Danube Canal defined by the medieval city walls which, between 1860 and 1880, were demolished and replaced by the Ring: an urban ring-road organising all major institutions of both civic and monarchical significance and connecting the old town with the dense urban areas developing around it. The medieval town had earlier been built upon the ruins of a
Roman military camp, Vindobona, which accounts now for the geometrical street layout of Vienna when compared with the more irregular street pattern that developed in the centre of the medieval city of Prague. At Vienna's centre is St. Stephen's Cathedral (Germ. Stephansdom), which by way of a series of pedestrian streets is linked to all of the city's main tourist attractions within the Ring - entry from which is either by the Opera House (Germ. Oper), or from Heroes' Square (Germ. Heldenplatz) by Hofburg Palace, formerly the Habsburg emperors' residence. Some historical sites are found outside the Ring, such as the Naschmarkt Market or important palaces like Belvedere Palace or the world-famous Schönbrunn Palace. Apart from these tourist attractions, there are also some new 


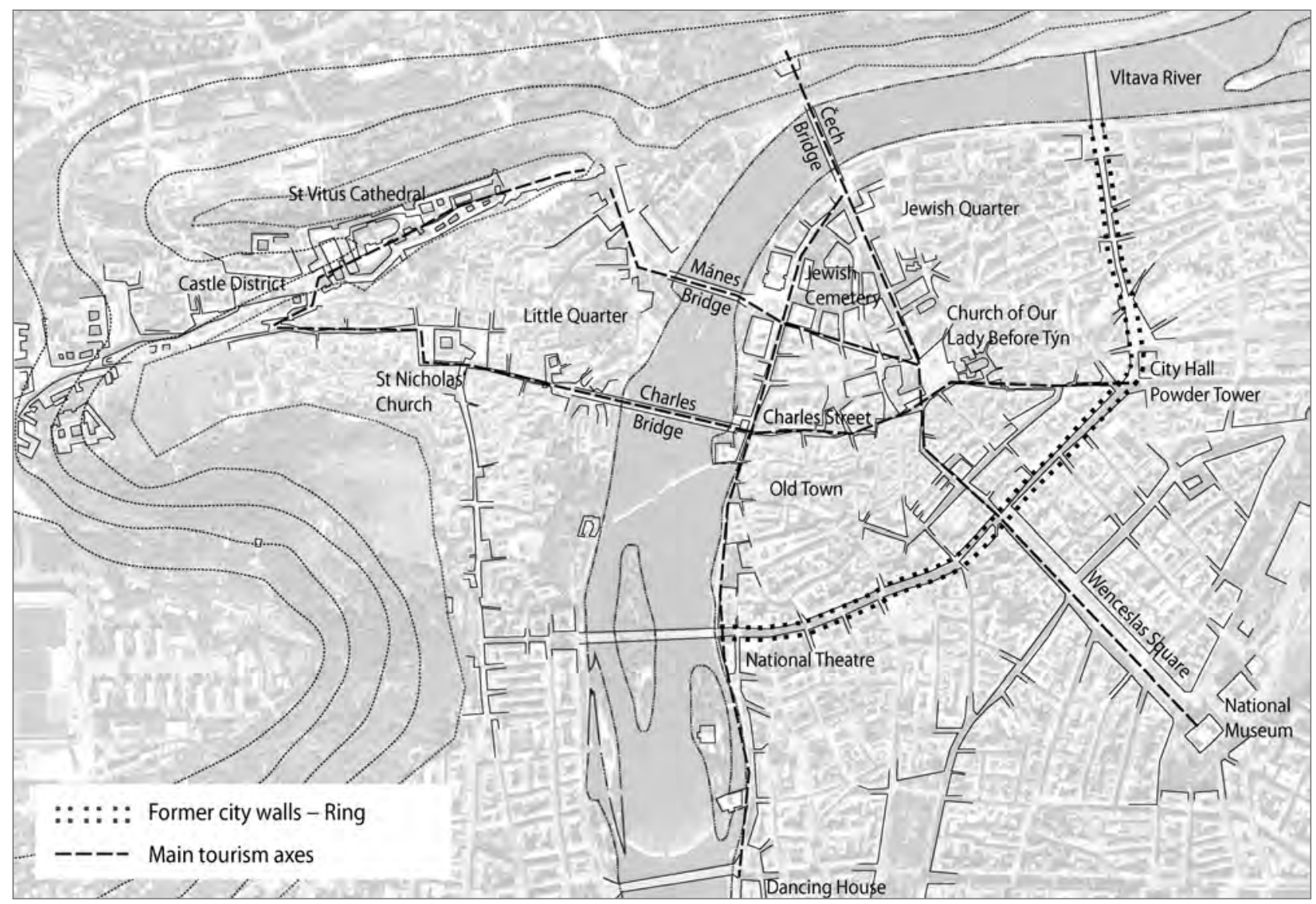

Figure 2: Main morphological and tourist elements in Prague.

leisure facilities recently developed on the Danube Canal and in the Museum Quarter (Germ. Museumsquartier), built near Hofburg Palace on the location of the former court stables.

By contrast, Prague has an organic character defined much more by topography. Although smaller in size and population than Vienna, it had a larger medieval core comprised of four towns on the two banks of the Vltava River. On the west side of the river the street pattern was predominately determined by the hilly topography in the Castle District (Cz. Hradčany) and the Little Quarter. On the less hilly east side the Old Town and the Jewish Quarter (Cz. Josefov) were limited by the eastern banks of the Vltava and by a semi-circular ring road, built in 1871 to replace the original baroque city walls. Despite having the National Theatre (Cz. Národni divadlo), Powder Tower (Cz. Prašná brána) and City Hall (Cz. Obecní $\mathrm{dim}$ ) on it, as well as being the start of Wenceslas Square (Cz. Václavské námèstí), Prague's ring road is not equal to Vienna's when considering the movement and flow of tourists around the city.

In Prague there are three important historical axes used today by most visitors. Charles Street (Cz. Karlova), part of "King's Way," is the oldest route of medieval origin linking the Old
Town from City Hall to the Little Quarter and the Castle District. All important tourist sites of the western side are accessible from it: the Bridge Gate (Cz. Mostecká), the St. Nicholas' Church and the Royal Palace complex, continuing the route to St. Vitus' Cathedral (Cz. Katedrála svatého Víta) and Golden Lane (Cz. Zlatá ulička). The second axis consists of two urban compositions from the nineteenth century, the 750-metre-long Wenceslas Square ending at the National Museum (Cz. Národní muzeum) on a small hill, and Paris Avenue (Cz. Parizská) ending at the Čech Bridge and a hill with a monumental park on the other side of the river. The river is the third axial element that connects the main points of interest. Conscious urban planning in the nineteenth and twentieth centuries placed some important institutions on the riverbank, where tourists look for reflected views of the city and visit the theatres, concert halls and museums on the embankments.

On the one hand, Vienna has a well-defined morphological structure with no obvious topographical constraints; Prague, on the other, has a more complex morphology resulting from a hotchpotch of four medieval towns that have grown together and a street pattern further distorted and confined by a hilly topography and the banks of a river. 


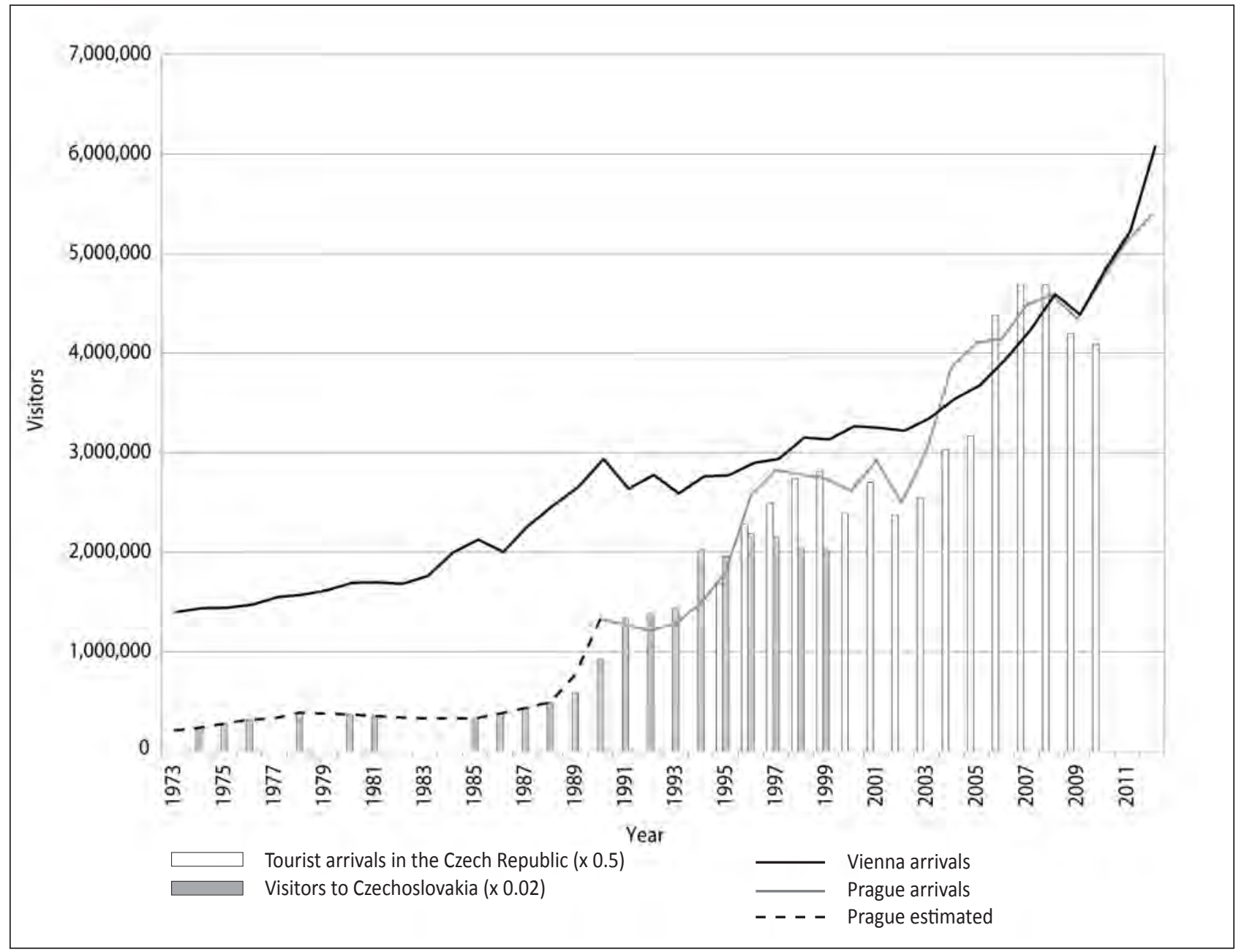

Figure 3: Tourist arrivals to Prague and Vienna between 1973 and 2011 (sources: Franke, 1984; Medlik, 1990; Maxwell, 1995; Hoffman \& Musil, 2009; TourMIS, 2012).

\subsection{Historical development of tourism industries}

In the EU today only Paris, Berlin, Rome, Barcelona and Madrid have more tourist arrivals than the 6,077,285 of Vienna and 5,394,283 of Prague (TourMIS, 2012). With both cities being historically similar and having a similar number of tourist visitors before the Second World War, Prague has caught up again with Vienna as a tourism destination after the fall of the Iron Curtain.

Up until the Second World War, when tourism was effectively curtailed, both cities attracted similar numbers of tourists. From 1925 to 1935 there were around half a million tourist visitors a year to Vienna; this number fell from a peak of 700,000 to below 400,000 in 1933, when an economic sanction by Germany, the Thousand Mark Barrier, was imposed on their nationals visiting Austria (Austrian Statistical Office, 1938). In the same period tourist arrivals to Prague grew from 300,000 visitors to more than 600,000 a year with a small drop in 1933-1934 (Czechoslovak Statistical Office, 1938).
During and after the war there are few statistics regarding these destinations. Following the Second World War the Iron Curtain effectively closed Prague to the booming expansion of tourism in the Western countries. It is important to understand the difference between the steady development of the tourism industry and visitor numbers in Vienna and Prague's sudden boom of tourists after an era of being closed off during the post-war period. Comparing the development of arrivals is a difficult quest because statistics similar to those gathered since 1955 by the Vienna Tourist Board and Statistics Austria are only available for Prague since 1991. Before that only some overall statistics of arrivals in Czechoslovakia and bed capacity without occupancy data exist (Franke, 1984). This lack of data was evident to previous researchers analysing trends in Czechoslovak and Prague tourism (Medlik, 1990; Maxwell, 1995; Hoffman \& Musil, 2009). Their findings and available statistical data (TourMIS, 2012) are used to build Figure 3, comparing tourist arrivals in Vienna and Prague. In this figure the available data for tourist arrivals in the Czech Republic are also marked to show the existing correlation between arrival 
numbers in the country and the capital, used to estimate past values of the latter.

Vienna was able to build its tourist infrastructure evenly over the past fifty years, maintaining its identity as a centre of classical music and guardian of the Habsburg traditions after the war. Austria regained independence when the allied troops left in 1955; in that same year the Vienna Tourist Board (originally the Vienna Tourist Association) was founded under the special Vienna Tourism Law. This not only established the independent professional management and regulation of Vienna's tourism industry but also the efficient tax collection and redistribution of earnings from the hotel industry. The 1.6 million bed nights registered in 1955 grew at a steady pace: they reached 3 million in 1964 and 4 million in 1975. In the 1980s 5 to 6 million tourist bed nights were registered, increasing to around 7 million in the 1990s and to 12.3 million in 2011. Tourism has been a major source of income for Austria, a militarily neutral country since the Second World War, wherein all players in this industry have been able to develop in a steady economic and political environment (TourMIS, 2012).

Prague as part of the Eastern Bloc had no chance for a similar course of development. The city lost many of its tourists after becoming part of the Soviet alliance with the 1948 Czechoslovak coup d'état. All hotels and services were nationalised, borders were closed and travel was restricted. With the requirement that every foreigner obtain a visa, the bureaucracy and open hostility to capitalism made it very difficult for Western tourists to enter Czechoslovakia. In the 1960s the government realised the benefits of Western tourists spending their hard currency but, even though the number of foreign tourists coming to the country rose from below 5 million in the 1960s to almost 19 million in 1986, more than $90 \%$ of all those visitors entering were from Eastern Bloc countries (Maxwell, 1995). This all changed dramatically after the Velvet Revolution in 1989. Visitors from post-communist countries almost disappeared then due to the recession during the first years of liberalisation, whereas new Western visitors started to explore the beauties of a previously closed city. From 1989 to 1993 these processes balanced each other, leading to a stagnation in tourism numbers, which boomed spectacularly only after 1993. The exoticism of the post-communist city faded fast, while the quality infrastructure and hotels needed to attract more tourists from richer countries were still lacking (Maxwell, 1995), resulting in another period of stagnation between 1997 and 2002. The extensive renovation of the centre of Prague has been a priority since the 1990 s, and many new hotels opened involving foreign capital. In 1990 there were 15,000 beds available in Prague, only double the number of the 1970s. This grew to 38,699 in 1996 and reached 50,000 in the first years of the 2000s (Hoffman \& Musil, 2009). These intensive infra- structure developments and the arrival of low-cost air carriers in the Czech capital created another boom in arrival numbers after the flood of 2002. Prague overtook its rival in 1997 for bed nights and in 2004 this was the case for arrival numbers as well. Today Prague is no longer a reminder of the communist era; it has become a well-preserved and well-exhibited urban jewellery box, with an up-to-date hotel industry and services.

However, in recent years Vienna has also caught up again. The arrival numbers of the two cities were head-to-head between 2008 and 2010 and show an advantage for Vienna today, which is also catching up in bed night numbers. Before the fall of the Iron Curtain, Vienna was visited by five times more tourists than Prague. The Austrian capital city lost many visitors with the opening of the borders: some from Western markets seeking new destinations in the newly opened Eastern cities and some from Eastern countries in recession. From Hungary alone more than 150,000 visitors arrived annually in the mid-1980s, but this number dropped to near 30,000 in the mid-1990s. Eastern Bloc citizens came to Austria before the end of the communist regime to shop for goods not accessible behind the Iron Curtain. The implementation of Western-style political systems made these visits obsolete, and it also imposed a period of economic recession on the post-communist countries in the early 1990s, setting back all forms of travel. To boost visitor numbers, Vienna diversified and further developed its tourist branding and cultural attractions in the 2000s. The new Museum Quarter opened in 2001, the Albertina Museum was renewed and reopened in 2008 and many other smaller interventions were made (Frantz, 2005). As a result, the Vienna Tourist Board was able to achieve its goal for 2010: registering more than 10 million bed nights, achieving considerable growth levels since the 2000s. If this tendency turns out to be a durable one it will prove that the planned tourism development model of Vienna is a more sustainable one than the unplanned liberalisation of Prague's tourism industry, which shows some negative impacts on both visitors' and locals' perceptions of the city.

\subsection{The impact of tourism}

Although tourism is beneficial to both cities at an economic level, the same number of tourists makes a different impact on social and urban life in them.

Vienna was named the most liveable city in the world for the fourth time in a row in 2012 by the international consulting firm Mercer. The Mercer Quality of Living Survey takes into consideration several criteria in defining a liveable city, and Prague is only sixty-ninth in this list. Vienna is second on the similar EIU Global Liveability Report, whereas Prague is sixtieth. The impact of tourism is not extensive in these aspects 

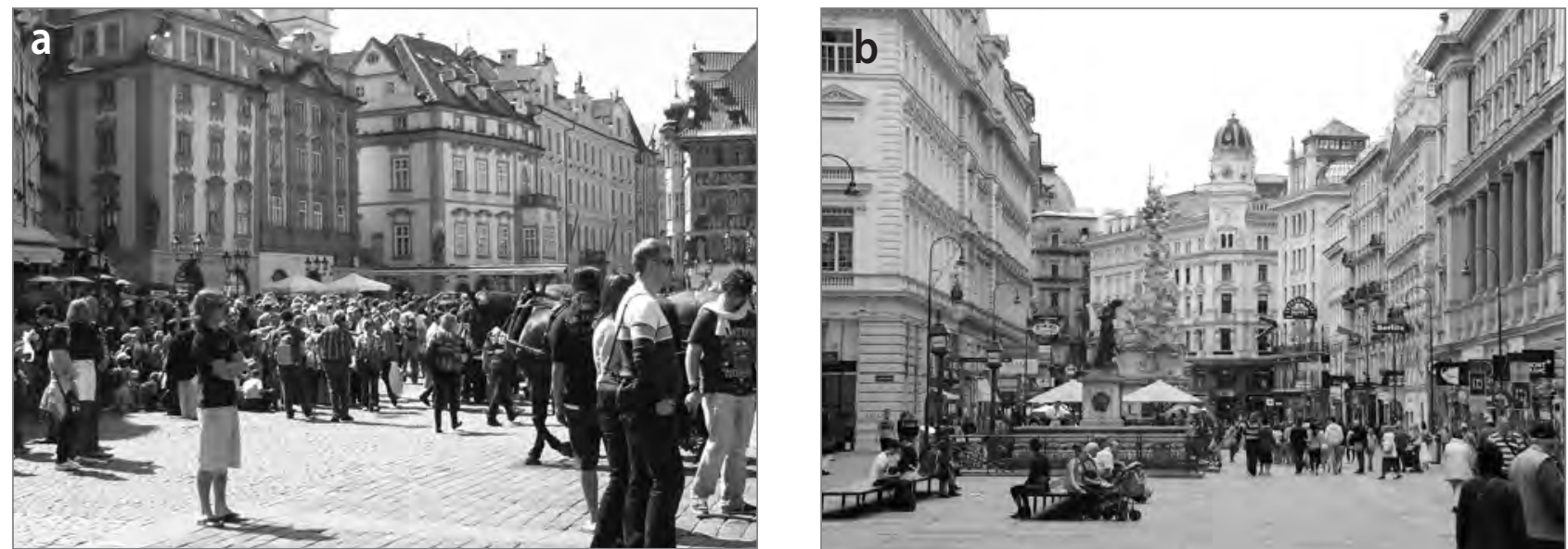

Figure 4: a) Tourist congestion in the historical centre of Prague, b) Graben in Vienna, the main pedestrian axis of the historical centre (photos: a) Bálint Kádár, b) Alex Diem).

but, because recreation and cultural opportunities greatly affect liveability, it is worth noting how tourists have occupied the most beautiful and valuable parts of the Czech capital, pushing locals out of the medieval squares and nearly all the areas surrounding the main cultural attractions.

This has not happened in Vienna. There are historical urban compositions with exclusive tourist use, such as the sites that best portray the brands of "Capital of Habsburgs" and "Capital of Music", but between these attractions all public spaces of the centre offer a mixture of services for tourists and locals alike. The recently developed extensions of the tourist network were planned as multifunctional environments, with plenty of services for locals as well. For instance, the Museum Quarter, which closes the main tourist axis of the Habsburg Court, is also a much-visited gathering space for young local people; movable urban furniture designed for that space also promotes this agora function. The urban rehabilitation of the area was planned since 1977, and the slow design process was always accompanied by large-scale discussion, resulting in constant compromises and redesigns until the opening in 2001 (Frantz, 2005). With the development of the Danube Canal embankment - the area where the tourist city and the business district meet - various business and leisure uses were implemented. It became a lively district with new bars, a river port and artificial beaches, used by locals and tourists alike (Hatz, 2008). The centre of Vienna is considered to be a premium environment for living, where carefully planned tourist uses complement services for locals.

Prague, on the other hand, faced drastic changes in the use of its historic core, leaving no time for comprehensive planning. After the fall of the Iron Curtain, the urgent privatisation and re-privatisation together with market liberalisation led to a rapid change in land uses in the centre (see Tsenkova, 2011). The most profitable property use was tied to tourism, and the booming numbers of tourists were served where they concentrated most, around the main sites of attraction. Entire buildings in the centre were converted from residential use to hotels and most street-front spaces changed to bars, restaurants and souvenir shops, transforming the once-rich cultural, shopping and residential urban fabric into a mono-functional tourist environment (Cooper \& Morpeth, 1998). There was no professional or social will to regulate the spatial or economic arrangement of the growing tourist industry because central planning was viewed as a communist method, and so the urban planning was negligible, even though a comprehensive Strategic Plan for Prague was created in 1996 (see Tsenkova, 2011). All this was a rapid process, leading to the socioeconomic tensions in the centre described by many researchers (Maxwell, 1995; Cooper \& Morpeth, 1998; Hoffman \& Musil, 1999; Simpson, 1999, Deichmann, 2002). The most obvious result was the rapid drop in the numbers of local population in the centre (Ourednicek \& Temelová, 2009), most visible around the "King's Way", a highly overcrowded succession of streets connecting all the main monuments (Simpson, 1999). The controversial "tourist takeover" of Prague gained the attention of many scholars in tourism studies, resulting in the research on tourism-related problems cited here, something that does not exist in the case of Vienna.

\section{Comparing the spatial patterns of urban tourism}

Understanding why the same number of tourists causes evident problems in Prague while no such problems are reported or observed in Vienna could lead to important spatial planning concepts conductive to an ideal balance of tourism and local life. It is assumed that the spatial distribution of the same number of tourists in these urban cores differs substantially, and that tourism related socioeconomic problems are less probable 


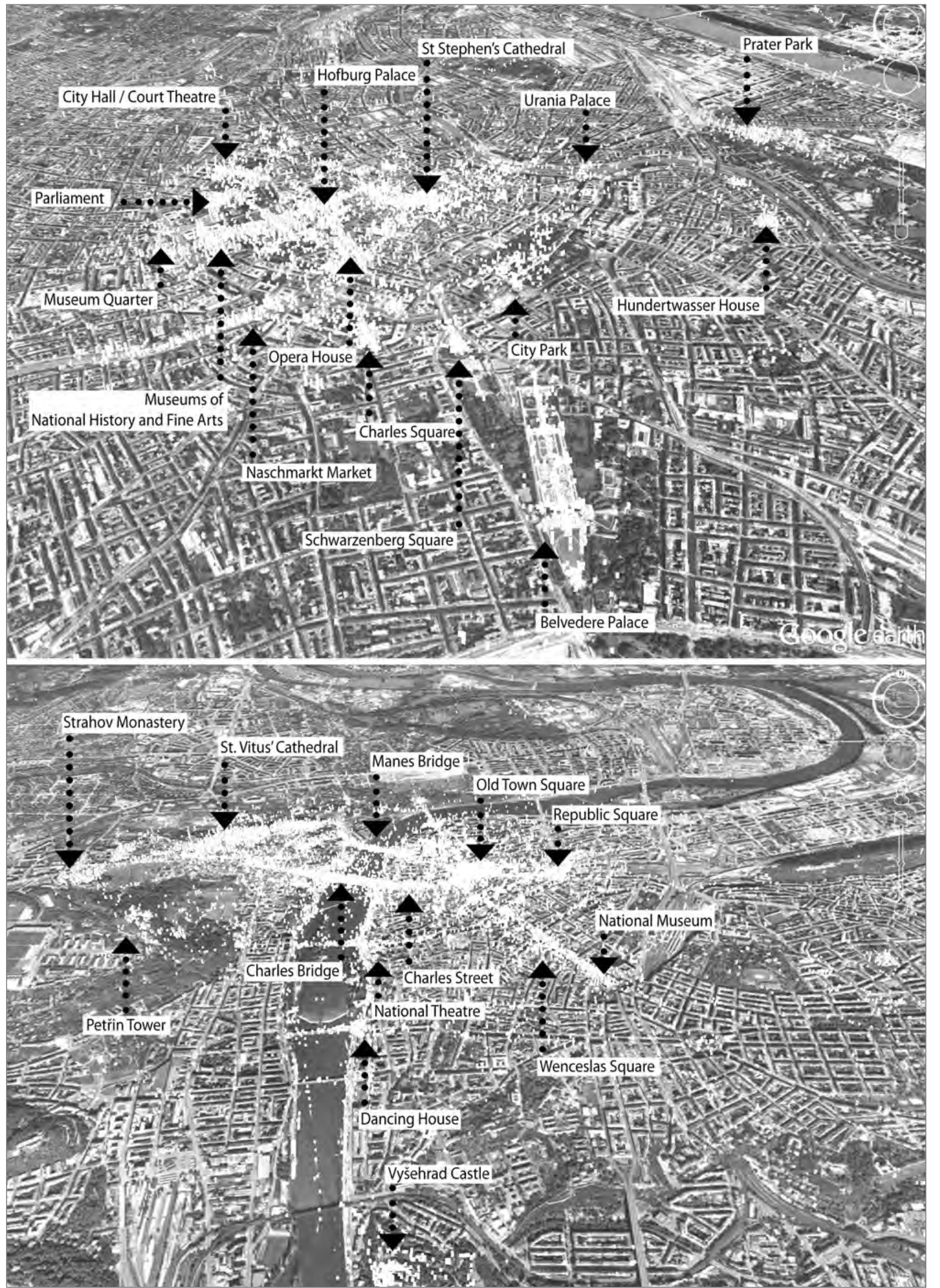

Figure 5: Position of geotagged photography in the centres of a) Vienna and b) Prague. 
in a more even network of tourist routes and attractions. The historically and topographically more regular urban grid in $\mathrm{Vi}$ enna must lead to a more even distribution of tourists, adjusted by the careful planning of tourism infrastructures and land use, than does the medieval urban grid of Prague confined by a river and steep hills, where tourism infrastructures developed over a few short years on the basis of demand, without urban planning considerations.

A method is needed to prove how the distribution of tourists in Vienna is more even than it is in Prague.

\subsection{Gathering data on tourists' urban space usage}

The lack of comparable models of urban tourism makes it difficult to prove such assertions. Tourists use urban environments in ways similar to all other users, and so it is hard to measure their movements and land use. Charles A. Stansfield argued that urban tourism is not quantifiable, and is thus ignored by researchers that are able to immerse themselves in more measurable rural tourism (1964). In past decades there has been progress in defining the spatial patterns of tourists' activities, and many studies tried to refine the basic model of urban tourism set up by Gregory Ashworth and John E. Turnbridge (1990) in The Tourist-Historic City.

The classic method of questionnaires and time-space diaries filled out by tourists yielded data on the visitor's gaze in urban space: Bob McKercher and Gigi Lau (2008) analysed the movement patterns of tourists, finding eleven movement styles; Noam Shoval and Adi Raveh (2004) were able to categorise clusters of attractions in Jerusalem visited by tourists with different characteristics; Bruce Hayllar and Tony Griffin (2005) were able to define the most important themes in tourist experiences related to the physical environment and atmosphere of the Rocks district in Sydney. The use of Global Positioning Systems (GPS) or mobile phone cell-information in tracking tourists allowed for more precise measurement of tourists' movements, defining patterns in space and time (Shoval \& Isaacson, 2010). Marko Modsching et al. (2008) used GPS tracking data to trace the activity areas of tourists, drawing the most visited hubs and paths in the German city of Görlitz. These methods enabled the collection and analysis of precise data on the spatial behaviour of tourists. All these studies helped to understand how an individual tourist moves in an urban context, but none of them could provide quantitative data on tourists' space usage. On the other hand, traditional forms of tourism statistics also do not measure the number of visitors moving around in the free public spaces of a tourist city. The available statistics are all based on the ticket-selling and visitor-counting at single attractions. Most urban tourists only enter a few of these venues, but they take photographs of many while strolling around, and these are not counted.

A possibility for defining tourist space use would be to analyse and localise tourist photography. In urban tourism the monuments, viewpoints and places of events are the primary objects of consumption. These are the places where tourists photograph themselves, creating records of their visit as the final proof that they did consume the experience offered by the city (Urry, 1990). Although the role of tourist photography in the experience was analysed after John Urry by many scholars (Jenkins, 2003; Larsen, 2006; Garrod, 2009) the possibility of extracting statistical data from the images of many tourists is still an emerging field. Today a relevant number of photographs with precise geographical data are uploaded and shared on social websites like Panoramio.com or Flickr.com. Tourists' motivation to record and share consumed personal experiences through their own photography meshes well with the possibilities offered by these online services. Geotagging these images permits tourists to link the images to exact places on the world map. Some cameras - including the growing number of smart phones - have built-in GPS antennas, allowing geotagging to be automated, while the manual placement of singular images on a map is also possible on these sites (Gede, 2012). The precisely geotagged images show a pattern that gives realistic information on the number of interested visitors.

Flickr.com (http://www.flickr.com) has more than 175 million geotagged images today, some 400,000 in the urban area of Vienna and 400,000 in Prague. The API of Flickr. com allows the analysis of all of these images; some emerging research focuses on the content and the given verbal tags of these images, relating them with the geographic position (Hollenstein \& Purves, 2010; Pang et al., 2011). Others explore the viewpoints of singular attractions, reconstructing visual information on landmarks (Ji et al., 2011; Crandall \& Snavely, 2012). Very few attempts have been made to retrieve quantitative tourism data from these databases. Exceptions are the studies analysing photographs uploaded to Flickr.com in the Province of Florence, Italy between 2005 and 2007 (Girardin et al., 2008), and in Budapest (Gede, 2012). Mátyás Gede generated diagrams from the numbers of photographs geotagged, making the points of interest visible on Google Earth. With his method it is possible to separate the photography of users that live and upload images from different time periods in the area analysed (locals) and users that do not upload images outside a restricted time period from that city (tourists). These visualisations and databases developed by Gede have been used in this study to retrieve data on the cities of Vienna (Figure 5a) and Prague (Figure 5b) from 2000 to 2011.

It is important to note that the users of image-sharing websites form only a small portion of all visitors. Studies confirm that 
the majority of tourists do take photos during their trips. A survey made among 1,466 households of Hong Kong by the Hong Kong Polytechnic University's School of Hotel and Tourism Management focusing on tourist photography and the use of social media to share it (Lo et al., 2011) showed that $89 \%$ of tourists interviewed took photographs during a trip. Out of these, $41.4 \%$ posted some of these pictures online, and $16.5 \%$ did this on sites like Flickr.com. The study revealed a strong relationship between the age and education of tourists and their desire to post their photos online. Oded Nov and Chen Ye (2010) confirmed that people that post travel photography to Flickr.com are more educated than the average, with a median age of 33 years. Still, the immense numbers of uploaded geotagged photographs can be a good statistical tool to confirm tourist space usages, even if the older generations of tourists are under-represented.

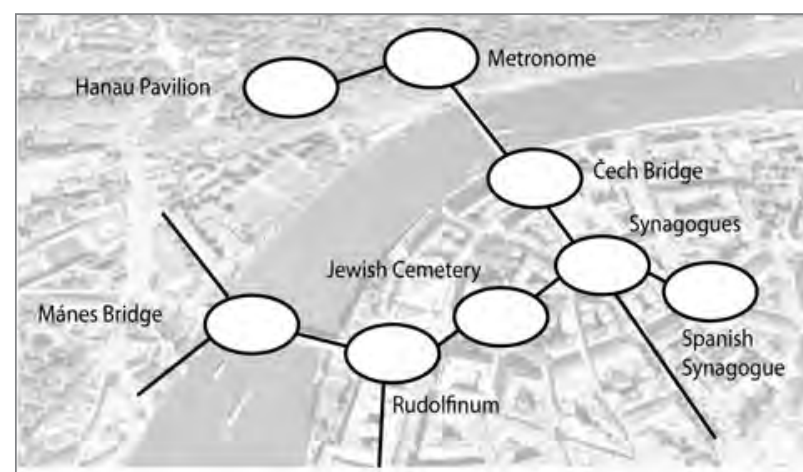

3. Abstraction into nodes and edges

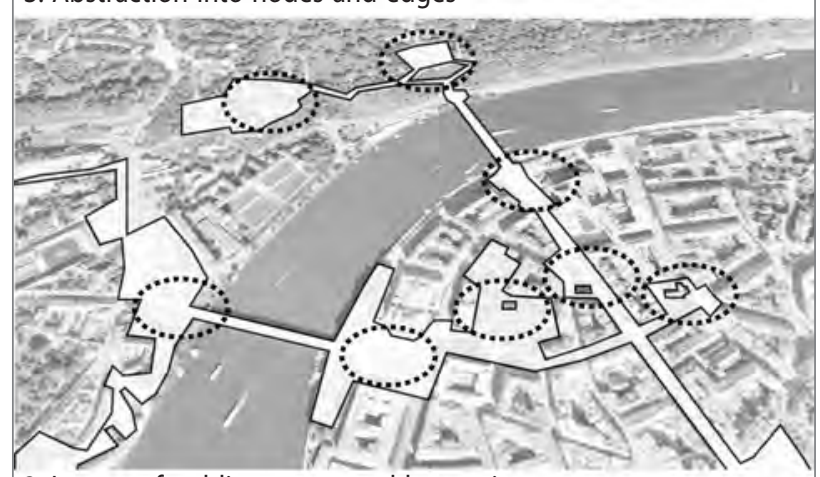

2. Layout of public spaces used by tourists

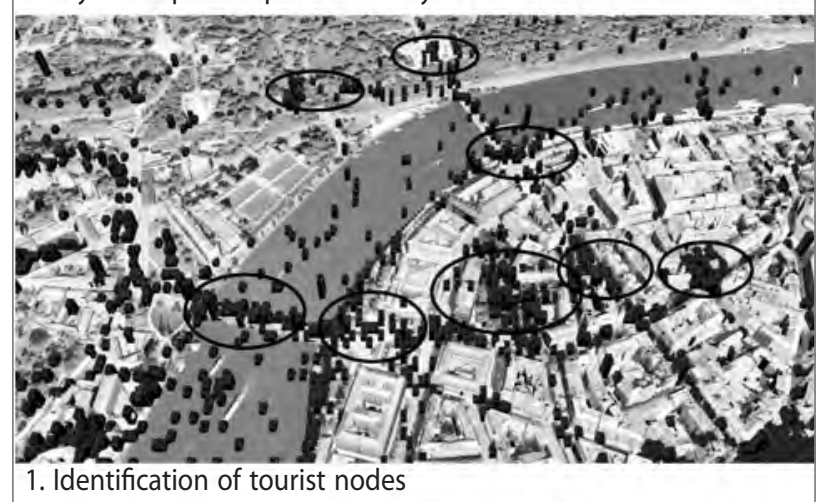

Figure 6: Creating mathematical graphs of tourist space usage from maps of geotagged photography.

\subsection{Graphs of tourist space usage}

Using maps generated from the Flickr.com databases, it is possible to create a mathematical graph describing the tourist space usage of cities. In an earlier study, I created such graphs from the uploaded photographs taken in Vienna, Prague and Budapest, analysing the changes in tourist uses in the past twenty years (Kádár 2012). In this article these data are used to compare the systems in Vienna and Prague in the present. The nodes of these graphs are not necessarily individual attractions, but continuous public spaces where tourists can visit and photograph attractions without moving further. The easily identifiable points of interest overlap the most important attractions recommended by travel guides, whereas the edges are the main tourist routes between these attractions, usually pedestrian priority roads (Figure 6). Knowledge of a given city's public space system is important in the construction of such graphs. Only routes accessible by pedestrians can be the edges connecting points of interest. Motorised transportation methods between tourist attractions are not taken into consideration because while using public transport or hop-on buses tourists are not present in the public spaces, do not cause pedestrian congestion and do not use other services on the streets.

Using graphs to describe urban spaces is not a new method. Previous works describing human usage and perception of cities with network representations help verify the validity of the comparative method chosen. Kevin Lynch in his famous work The Image of the City defined five elements that users of urban environments use to describe their environments (Lynch, 1960). Cities have different mental districts, where the paths and edges define human movement and nodes and landmarks are the important places. Lynch did not analyse the mental maps as mathematical networks. It was Christopher Alexander (1965) that studied the nature of urban spaces and functions with networking principles in "A City is Not a Tree". In fact, Alexander notes the disadvantages of the tree structure for urban forms: when functions are arranged one after another with few branches and no alternative pathways. He points out the semi-lattice structures of living cities, where spaces are arranged with good networking and many intersecting branches. His work and the mathematical approach to urban structures have inspired many scholars seeking to describe the complex networks of cities. Nikos Salingaros $(2004,2005)$ summarises some of the most important principles used to break down the complexity of urban systems into graphs consisting of nodes and edges.

Aspa Gospodini (2001) uses such graphs to interpret the tourist use of urban spaces, defining the role of urban morphology in tourist satisfaction and tourism-related developments. She also points out the negative effects of a tree structure and the 


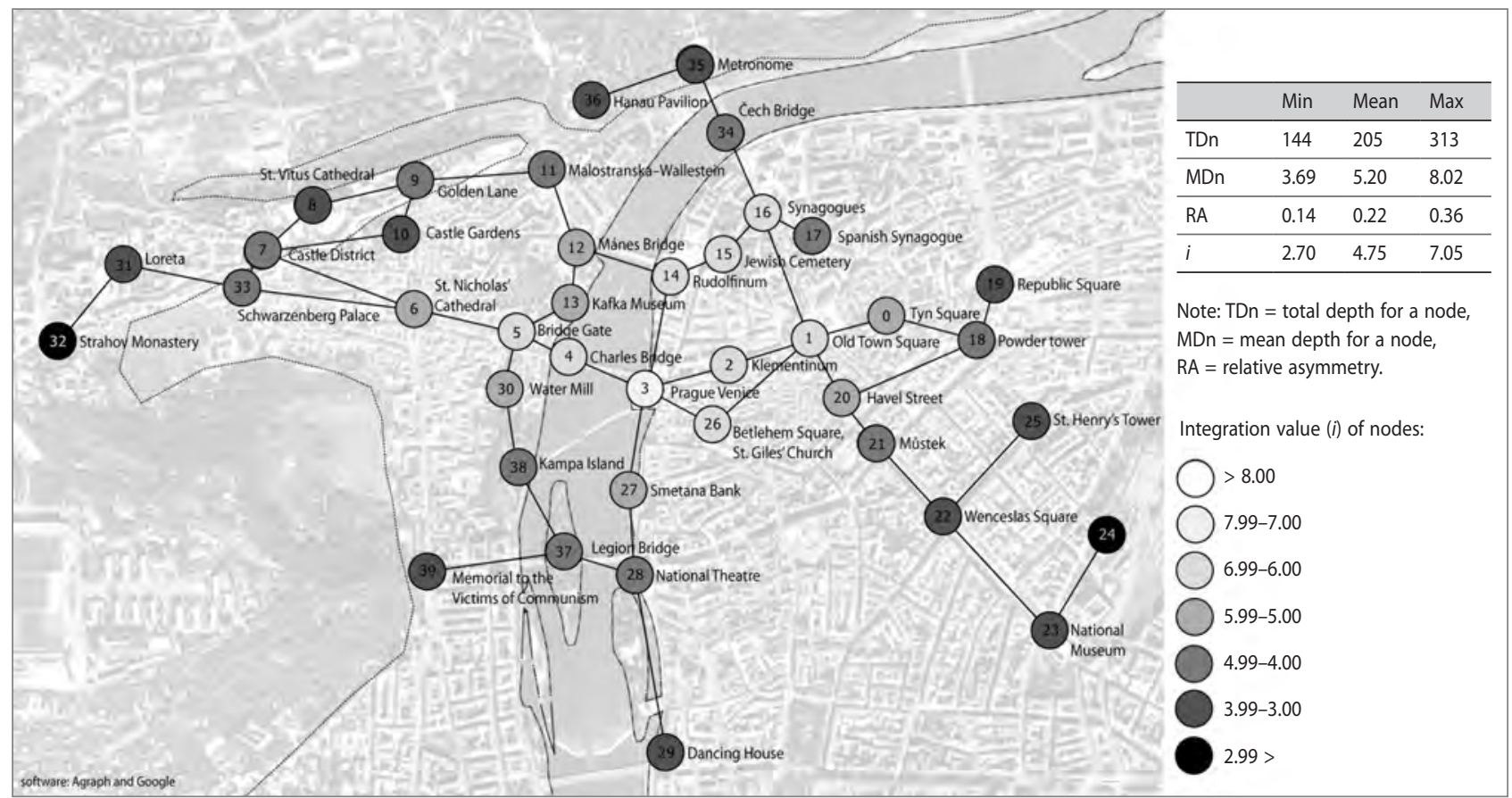

Figure 7: Pedestrian tourist space system of Prague in 2011.

liveliness of a semi-lattice structure in urban spaces, referring to the principle of simultaneous and successive arrangements described by Henk W. J. Boerwinkel (1995), stating that the lattice is more attractive to tourists because it offers more choices of exploration and thus more freedom, an essential value in leisure activities. Gospodini proposes a space syntax analysis of tourism networks, a method of analysing syntactic space systems introduced by Bill Hillier (1996). Hillier's method is an abstraction of architectural and urban space into mathematical graphs, with an evolving field of studies using it today. Analysing the connectivity of attractions with space syntax will result in the numerical expression of the syntactic depth of the resulting graphs. To achieve this only basic depth calculations are needed, integrated for the entire graph. The evaluation of the Vienna and Prague graphs is based on calculations using Agraph software for space syntax in node mode. To compare the graphs, the integration value $i$ introduced in Agraph, calculated from the mean depth $(M D)$, is used. The methods of calculation are the following (Manum et al., 2005):

$i=1 / R A$

$R A=2 *(M D-1) /(K-2)$

$M D=T D /(K-1)$

$R A$ is the relative asymmetry, $K$ is the number of nodes and $T D$ is the total depth for a node. The integration value $i$ describes the level of integration of one node into the system. The mean integration value is the average of these values, and together with minimum and maximum values shows the overall connectedness of the system. The higher the mean integration value - and the higher the lowest integration value in the sys- tem - the less poorly connected the nodes are with the rest of the system. This means there are fewer routes crowded by visitors that have been forced to travel from one part of the system to another using the same pathway.

\subsection{Comparing the tourist space usage of Vienna and Prague}

To make the graphs comparable, the first forty interconnected points of interest were selected. This was not difficult due to the similarity of the tourist attractions of these cities. It is important to omit attractions not in walking distance to the interconnected parts of the graph. Vienna has important tourist sites outside the centre such as Prater Park or Schönbrunn Palace, and the Hundertwasser buildings also fall outside of the integral system. In Prague, Vyšehrad Castle and the Petrín lookout tower are the most visited sites outside the pedestrian system of the centre.

The integral tourist networks follow the historically evolved morphological structures described above. The graphs of the two cities show some important differences. In Prague the three axes described are clearly visible (Figure 7). Tourists do use the Mánes Bridge and the castle stairs to connect the castle with the old Jewish Cemetery, the synagogues and the rest of the space system they move in, but very few similar connections exist, and so the graph consists of many nodes having only two connecting edges - points of interests on tourist routes with no options to depart from that path. The most integrated points are on Charles Street, from the Charles Bridge to Old 


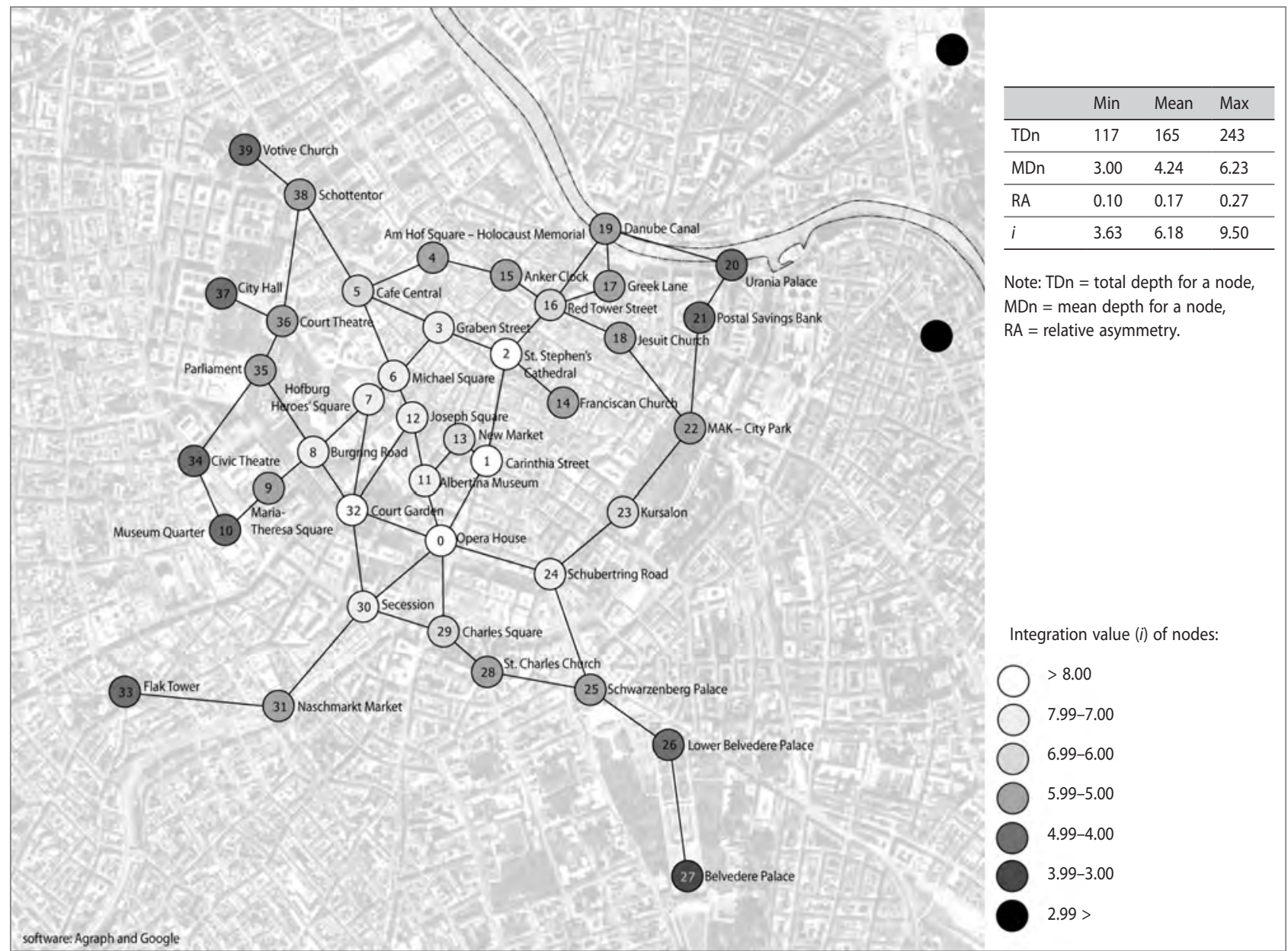

Figure 8: Pedestrian tourist space system of Vienna in 2011.
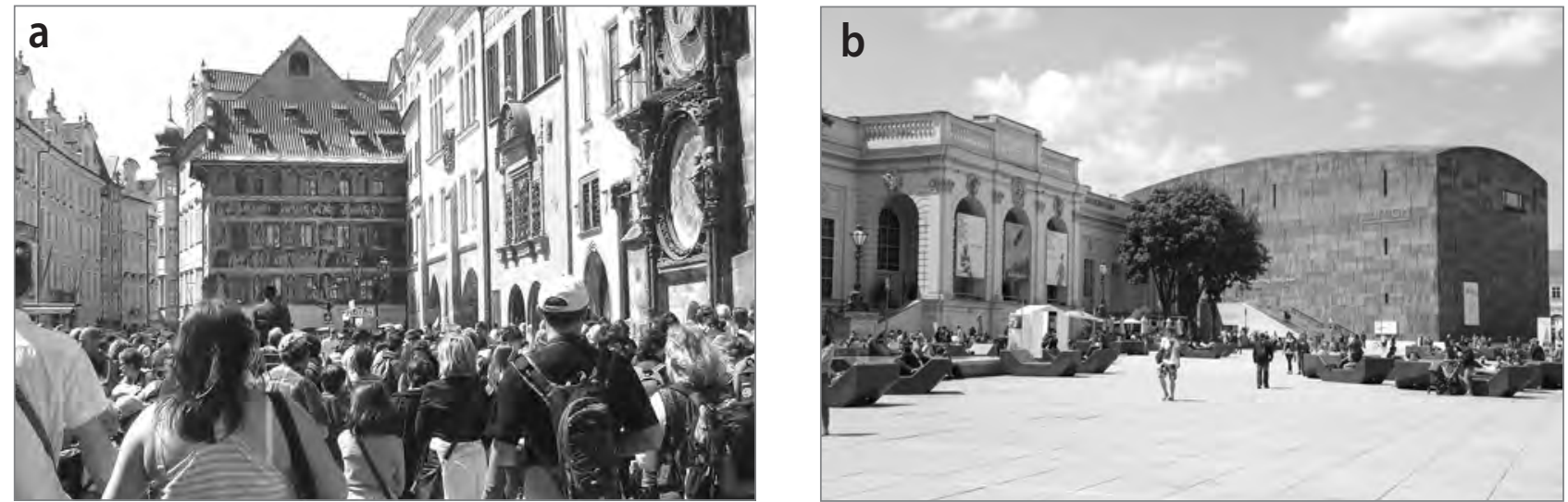

Figure 9: a) Tourist congestion in the historical centre of Prague: Old Town Square, b) Museum Quarter in Vienna: MUMOK museum and mobile furniture (photos: a) Bálint Kádár, b) Alex Diem).

Town Square (6.50-7.05). In fact, all tourists pass this section at least once. The minimum value is below 3 , and $30 \%$ of all nodes have integration values below 4 . The mean integration value is 4.75 , a number that is interesting only if compared to other systems.

Vienna has a well-interconnected central system held together by the edges and nodes on the Ring (Figure 8). The system reaches some attractions outside the ring, such as the Museum
Quarter, the Naschmarkt Market and Belvedere Palace; these three are tree-like branches. The space syntax graph shows that the most integrated nodes in the network are around the Opera House, which has an integration value of 9.62. Nodes around the centre all have values above 7.00 , which is the maximum value in Prague. Minimum values are all above 4, except for the southern end of Belvedere Palace. The whole central tourist network of Vienna has a mean integration value of 6.16, which is remarkable compared to that of Prague. 
In fact, the graph of Vienna shows a compact but complex network, where tourists have various options to look around the city centre between the attractions. The graph of Prague shows that this city has fewer options for tourists to discover new spaces than in Vienna, whereas the amount of attractions is the same. The reasons for such a low value are first of all the special morphology of the city with the topographical limitations on the west side of the river, the river itself, the labyrinthine medieval street pattern of the Old Town with one main path marked, and the incapacity of the ring road on the eastern side of Prague to link the three tourist axis described above. Some recent developments in Prague have helped make a more complex system for tourists. The castle stairs and castle gardens have been renovated in the past decades to give new routes to tourists visiting the castle. New attractions have been created on the riverbanks, like the Metronome on the north side, or the Dancing House, the Memorial to the Victims of Communism and the Kampa Museum on the south side. But all European cities have made similar developments extending their cultural attractions, and Vienna was no exception. The Museum Quarter and developments by the Danube Canal were the most important interventions extending the already-dense tourist network (Kádár, 2012).

\section{Conclusion}

These two Central European cities have a similar number of attractions and similar cultural settings, and have been visited by the same number of tourists in recent years (uploading the same number of travel photographs), but Vienna does not suffer the same negative effects of tourist congestion that Prague does. The unique morphology of each tourist-historic city and the different patterns of arrangement of their main attractions and tourist infrastructures are in part responsible for their imbalanced tourist uses. The graph model for analysing the system of public spaces used by tourists helps highlight these differences.

The differing tourist use of the two cities is mostly of a morphological nature. Vienna has a balanced network of tourist uses, the morphological system of the centre is clear and the main barrier of its historical centre - the medieval walls - was not only demolished during the nineteenth century, but main institutions - now attractions - were built in its place, creating an integrative ring that keeps all tourist sites inside and outside of it connected. Prague has many morphological constraints that block the integration of its tourist networks. A river divides the centre, and a hilly topography impedes the growth of a well-connected road network. The labyrinthine medieval street pattern, an urban arrangement serving defensibility, was preserved in Prague, where preservationist movements were strong from the early nineteenth century (Hoffman \& Musil,
1999). Urban development could only make the system more accessible with the construction of new bridges and some large urban compositions connecting the centre with peripheral areas.

It is hardly possible to revise the urban morphology in tourist-historic cities. However, inside the given urban structures the tourist system uses only some of the public spaces and buildings, and the number of these can be extended. The dispersion of the same number of tourists in more space results in less overcrowding. Therefore there is another component over morphology that determines the tourist uses of a city: the urban planning of the tourist infrastructures. Vienna had more than fifty years of stable and conscious urban development, during which tourism management and urban planning were well-established sectors of governance. It is also important that the wealth of the population grew apace with arrival numbers, allowing local inner city services to develop together with those serving tourists. In Prague there was no possibility for such a balanced and planned growth trajectory. After the fall of the Iron Curtain the decentralisation of state power and the liberalisation of all markets happened simultaneously with the sudden rise in tourist arrivals. Infrastructure serving tourism occupied most of the re-privatised real estate near the favoured tourist sites, situated principally along the most important historical routes inside the city.

These differences are clearly visible on the graphs of tourist space usage. The integration numbers calculated from the depths of the graphs gives numeric evidence of how much more interconnected the attractions of Vienna are, resulting in more public spaces used by the same number of tourists. Prague's system has a mean integration value of 4.75 compared to the 6.16 of Vienna with the same number of nodes. This results in overcrowding for tourists visiting Prague because they must pass through certain public spaces several times to visit all attractions. The negative effects of this network - like the decreasing use of Prague's centre by locals and diminishing quality of tourist experiences in the congested streets - have been reported by many scholars (Johnson, 1995; Cooper \& Morpeth, 1998; Simpson, 1999; Deichmann, 2002). No such problems have been published in the case of Vienna, where more public spaces welcome the same amount of visitors and thus the services are also dispersed, leaving space for local uses and local users.

Bálint Kádár

Budapest University of Technology and Economics, Faculty of Architecture, Department of Urban Planning and Design, Budapest, Hungary

E-mail: balint.kadar@gmail.com 


\section{References}

Alexander, C. (1965) A city is not a tree. Architectural Forum, 122(1), pp. 58-61 and 122(2), pp. 58-62.

Ashworth, G. J. \& Turnbridge, J. E. (1990) The tourist-historic city. London, Belhaven Press.

Austrian Statistical Office (1938) Statistisches Jahrbuch für Österreich 1938. Vienna, Österreichisches Statistisches Landesamt.

Boerwinkel, H. W. J. (1995) Management of recreation and tourist behaviour at different spatial levels. In: Ashworth, G. J. \& Dietvorst, A. G. J. (eds.) Tourism and spatial transformations - implications for policy and planning, pp. 241-263. Wallingford, CAB International.

Bugarič, B. (2006) Transformation of public space, from modernism to consumerism. Urbani izziv, 17(1-2), pp. 173-176.

DOI: 10.5379/urbani-izziv-en-2006-17-01-02-001

Cooper, C. \& Morpeth, N. (1998) The impact of tourism on residential experience in Central-Eastern Europe: The development of a new legitimation crisis in the Czech Republic. Urban Studies, 35(12), pp. 22532275. DOI: $10.1080 / 0042098983872$

Crandall, D. \& Snavely, N. (2012) Modeling people and places with internet photo collections. Communications of the ACM, 55(6), p. 52. DOI: 10.1080/0042098983872

Czechoslovak Statistical Office (1938) Visitors to the spas of Czechoslovakia and to the capital, Prague. Prague.

Deichmann, J. I. (2002) International tourism and the sensitivities of central Prague's residents. Journal of Tourism Studies, 13(2), pp. 41-52.

Franke, A. (1984) Rukovět' cestovního ruchu. Prague, Merkur.

Frantz, M. D. (2005) From cultural regeneration to discursive governance: Constructing the flagship of the "Museumsquartier Vienna" as a plural symbol of change. International Journal of Urban and Regional Research, 29(1), pp. 50-66. DOI: 10.1111/j.1468-2427.2005.00569.x

Garrod, B. (2009) Understanding the relationship between tourism destination imagery and tourist photography. Journal of Travel Research, 47(3), pp. 346-358. DOI: 10.1177/0047287508322785

Gede, M. (2012) Visualization methods of spatial distribution of geotagged photography. Paper presented at the Data is Beautiful Conference, 2-6 October, Budapest, Hungary. Typescript.

Gilbert, D. \& Clark, M. (1997) An exploratory examination of urban tourism impact, with reference to residents attitudes, in the cities of Canterbury and Guildford. Cities, 14(6), pp. 343-352.

DOI: 10.1016/S0264-2751(97)00025-5

Girardin, F., Fiore, F. D., Ratti, C. \& Blat, J. (2008) Leveraging explicitly disclosed location information to understand tourist dynamics: A case study. Journal of Location Based Services, 2(1), pp. 41-56. DOI: $10.1080 / 17489720802261138$

Gospodini, A. (2001) Urban design, urban space morphology, urban tourism: An emerging new paradigm concerning their relationship. European Planning Studies, 9(7), pp. 925-934. DOI: $10.1080 / 09654310120079841$

Hatz, G. (2008) Vienna. Cities, 25(5), pp. 310-322.

DOI: 10.1016/j.cities.2008.02.002

Hayllar, B. \& Griffin, T. (2005) The precinct experience: A phenomenological approach. Tourism Management, 26(4), pp. 517-528. DOI: 10.1016/j.tourman.2004.03.011

Hillier, B. (1996) Space is the machine. Cambridge, Cambridge University Press.
Hoffman, L. M. \& Musil, J. (1999) Culture meets commerce: Tourism in postcommunist Prague. In: Judd, D. \& Fainstein, S. (eds.) The Tourist City, pp. 179-197. New Haven, Yale University Press.

Hoffman, L. M. \& Musil, J. (2009) Prague, tourism and the post-industrial city. Tourism. Chicago, Great Cities Institute College of Urban Planning and Public Affairs University of Illinois at Chicago.

Hollenstein, L. \& Purves, R. S. (2010) Exploring place through user-generated content: Using Flickr to describe city cores. Journal of Spatial Information Science, 1(1), pp. 21-48.

Jenkins, O. H. (2003) Photography and travel brochures: The circle of representation. Tourism Geographies, 5(3), pp. 305-328. DOI: 10.1080/14616680309715

Ji, R., Gao, Y., Zhong, B., Yao, H. \& Tian, Q. (2011) Mining flickr landmarks by modeling reconstruction sparsity. ACM Transactions on Multimedia Computing, Communications, and Applications, 7S(1), pp. 1-22. DOI: $10.1145 / 2037676.2037688$

Johnson, M. (1995) Czech and Slovak tourism patterns: Problems and prospects. Tourism Management, 16(1), pp. 21-28. DOI: 10.1016/0261-5177(94)00003-S

Kádár, B. (2012) Spatial patterns of urban tourism in Vienna, Prague and Budapest. In: Szirmai, V. \& Fassmann, H. (eds.) Metropolitan Regions in Europe, pp. 277-312. Budapest, Austrian-Hungarian Action Fund.

Larsen, J. (2006) Geographies of tourist photography choreographies and performances. In: Falkheimer, J. \& Jansson, A. (eds.) Geographies of Communication: The Spatial Turn in Media Studies, pp. 241-258. Göteborg, Nordicom.

Lo, I. S., McKercher, B., Lo, A., Cheung, C. \& Law, R. (2011) Tourism and online photography. Tourism Management, 32(4), pp. 725-731. DOI: 10.1016/j.tourman.2010.06.001

Lynch, K. (1960) The image of the city. Cambridge, MA, MIT Press.

Manum, B., Rusten, E. \& Benze, P. (2005) AGRAPH, software for drawing and calculating space syntax graphs. Paper presented at the 5th International Space Syntax Symposium Delft 2005, 13-17 June, Delft, Netherlands, pp. 97-101. Typescript.

McKercher, B. \& Lau, G. (2008) Movement patterns of tourists within a destination. Tourism Geographies, 10(3), pp. 355-374. DOI: 10.1080/14616680802236352

McNeil, D. (1999) Globalisation and the European city. Cities, 16(3) pp. 143-147. DOI: 10.1016/S0264-2751(99)00012-8

Medlik, S. (1990) Current issues focus on Eastern Europe. Tourism Management, 11(2), pp. 95-98. DOI: 10.1016/0261-5177(90)90023-3

Modsching, M., Kramer, R., Hagen, K. Ten \& Gretzel, U. (2008) Using location-based tracking data to analyze the movements of city tourists. Information Technology \& Tourism, 10(1), pp. 31-42. DOI: $10.3727 / 109830508785059011$

Nov, O. \& Ye, C. (2010) Why do people tag? Motivations for photo tagging. Communications of the ACM, 53(7), pp. 128-131. DOI: 10.1145/1785414.1785450

Ourednicek, M. \& Temelová, J. (2009) Twenty years after socialism: the transformation of Prague's inner structure. Studia Universitatis Babes-Boyai, Sociologia, 54(1), pp. 9-30.

Pang, Y., Hao, Q., Yuan, Y., Hu, T., Cai, R. \& Zhang, L. (2011) Summarizing tourist destinations by mining user-generated travelogues and photos. Computer Vision and Image Understanding, 115(3), pp. 352-363. DOI: 10.1016/j.cviu.2010.10.010

Puczkó, L. \& Rátz, T. (2000) The three forming one: Destination BPV. In: Ruddy, J. \& Flanagan, S. (eds.) Tourism Destination Marketing. Gaining 
the Competitive Edge, pp. 367-377. Dublin, Tourism Research Centre Dublin Institute of Technology.

Riganti, P. \& Nijkamp, P. (2008) Congestion in popular tourist areas: A multi-attribute experimental choice analysis of willingness-to-wait in Amsterdam. Tourism Economics, 14(1), pp. 25-44. DOI: $10.5367 / 000000008783554785$

Salingaros, N. A. (2004) Remarks on a city's composition. Journal of Design Research, 4(1). DOI: 10.1504/JDR.2004.009844

Salingaros, N. A. (2005) Principles of urban structures. Amsterdam, Techne Press.

Shoval, N. \& Isaacson, M. (2010) Tourist mobility and advanced tracking technologies. New York, Routledge. DOI: 10.1016/j.tourman.2003.09.005

Shoval, N. \& Raveh, A. (2004) Categorization of tourist attractions and the modelling of tourist cities: Based on the co-plot method of multivariate analysis. Tourism Management, 25(6), pp. 741-750.

Simpson, F. (1999) Tourist impact in the historic centre of Prague: Resident and visitor perceptions of the historic built environment. The Geographical Journal, 165(2), pp. 173-183. DOI: 10.2307/3060415

Stansfield, C. A. (1964) A note on the urban-nonurban imbalance in American recreational research. Tourism Review, 19(4), pp. 196-200.

TourMIS (2012) City tourism in Europe. Available at: http://www.tourmis. info (accessed 10 Jan. 2012).

Tsenkova, S. (2011) Venturing into unknown territory: Strategic spatial planning in post-communist cities. Urbani izziv, 22(1), pp. 83-99. DOI: 10.5379/urbani-izziv-en-2011-22-01-001

Urry, J. (1990) The tourist gaze - leisure and travel in contemporary societies. London, SAGE publications. 